\title{
CORRELATION BETWEEN COMPENSATION AND WORK SATISFACTION WITH NURSES' PERFORMANCE THROUGH MOTIVATION IN BETHESDA PUBLIC HOSPITAL OF TOMOHON
}

\author{
Chyntia Novita Kalalo', Elly L. Sjattar ${ }^{2}$, Rosdiana Natzir ${ }^{3}$ \\ ${ }^{1}$ Universitas Musamus Merauke \\ ${ }^{2}$ Program Studi Magister Ilmu Keperawatan Fakultas Keperawatan Universitas Hasanuddin \\ ${ }^{3}$ Fakultas Kedokteran Universitas Hasanuddin \\ email : chyntiakalalo@gmail.com
}

\begin{abstract}
Introduction: Compensation provided by hospital and job satisfaction of nurses can affect the performance of nurses. The research aimed to analyze the correlation between compensation and work satisfaction with nurses' performance through motivation in inpatient room of Bethesda Publik Hospital of Tomohon. Method: The method used is analytic observational approach with cross sectional study. The number of sample were of 50 respondents. The methods of obtaining the data were questionnaire with Likert scale and observation of nurses' performance with Guttman scale. The data were analyzed using univariate and bivariate analysis by means of frequency distribution table and cross tabulation with chi square. Results: The research indicate that compensation has a correlation with work load $(p=0.003)$, motivation $(\mathrm{p}=0.040)$, and nurses' performance $(\mathrm{p}=0.001)$. Work satisfaction has a correlation with motivation $(p=0.002)$ and nurses' performance $(p=0.000)$. Motivation has a correlation with nurses' performance $(p=0.013)$. Conclusion: The management of the hospital should pay attention to compensation given and nurses' work satisfaction, so the nurses are more motivated to carry out services in a professional nursing care in order that more optimal nurses' performance.
\end{abstract}

Keywords: Compensation, Work Satisfaction, Motivation, Nurses’ Performance

\section{PENDAHULUAN}

Sumber Daya Manusia (SDM) adalah sumber daya yang paling utama dalam setiap organisasi yang sangat berperan dalam mencapai tujuan organisasi tersebut dengan melaksanaan pekerjaan tertentu. SDM dalam rumah sakit yang paling penting dan sangat dibutuhkan adalah tenaga kesehatan. Dalam menjalankan tugas dan kerjanya, untuk mencapai tujuan dari rumah sakit dalam meningkatkan kinerja agar optimal, tenaga kesehatan memiliki berbagai kebutuhan yang harus dipenuhi oleh manajemen rumah sakit (Siboro, 2012).

Rumah Sakit Umum Bethesda Tomohon adalah rumah sakit swasta milik Yayasan Medika yang berada di Kota Tomohon, Provinsi Sulawesi Utara. Dimana diketahui bahwa tahun 2014
RSU Bethesda Tomohon didukung oleh 444 orang tenaga medis dan non medis, dimana 142 orang (32\%) di antaranya merupakan tenaga keperawatan, $107(75 \%)$ perawat bertugas di ruang rawat inap dan rawat inap khusus. Dengan jumlah ruangan perawatan yaitu 6 ruangan dimana BOR rata-rata setiap ruangan pada bulan Januari 2015 adalah Bethesda 92,86\%, Debora 96,30\%, Yohanes 73,92\%, Markus $72,73 \%$, Paulus $84,62 \%$ dan Elisabeth $97,92 \%$. Jumlah perawat di ruang rawat inap pada Desember 2014 yaitu 78 perawat termasuk kepala ruangan dengan pendidikan S1,Ns., D4, D3 dan SPK. Pada Januari 2015, perawat yang bekerja di ruangan rawat inap meningkat menjadi 82 perawat. Dengan jumlah tempat tidur 160 TT, perbandingan ratio dengan 
jumlah perawat adalah 2:1, sudah sesuai dengan perhitungan jumlah perawat menurut Depkes. Didalam penilaian kepuasan kerja perawat belum dilaksanakan tetapi hanya dilakukan dengan melihat evaluasi akhir kerja perawat yang sekaligus dilihat penilaian kinerja perawat. Penilaian kinerja perawat dievaluasi dari bidang keperawatan. Banyak perawat yang merasakan belum sesuai antara beban kerja dengan kompensasi yang diberikan oleh pihak manajemen Rumah Sakit. Hal ini yang membuat perawat merasa kurang puas dan terjadi penurunan motivasi dalam bekerja.

Kompensasi merupakan salah satu fungsi yang penting dalam Manajemen Sumber Daya Manusia (MSDM). Kompensasi adalah total seluruh imbalan yang diterima karyawan sebagai pengganti jasa yang telah mereka berikan (Mondy et al., 2008). Perawat dapat melaksanakan pekerjaannya jika ditunjang dari pemberian kompensasi baik kompensasi financial maupun non financial, sehingga timbul motivasi dan kepuasan kerja perawat akan dapat meningkatkan kinerja perawat dalam melaksanakan asuhan keperawatan (Ngatemin \& Arumwanti, 2012).

Kepuasan kerja mengacu pada sikap umum karyawan terhadap pekerjaannya. Orang yang kepuasan kerjanya tinggi akan bersikap positif terhadap pekerjaannya, sedangkan orang yang kecewa terhadap pekerjaannya akan bersikap negative (Robbins, 2006). Hasil dari penelitian menyebutkan bahwa semakin tinggi kepuasan kerja yang dirasakan oleh perawat maka akan semakin baik kinerja perawat (Wahono, 2012).

Motivasi juga dapat mempengaruhi kinerja dalam organisasi. Seorang yang profesional tidak dapat melepaskan diri dari kenyataan bahwa mereka adalah individu yang mempunyai kebutuhan, keinginan, dan harapan dari tempatnya bekerja (Manurung, 2013).
Tanpa adanya motivasi seorang karyawan tidak akan bekerja secara optimal karena ketiadaan dorongan bagi dirinya dalam melaksanakan berbagai tugas yang akan dibebankan kepadanya (Winardi, 2007).

Kinerja perawat adalah aktivitas perawat dalam mengimplementasikan sebaik-baiknya suatu wewenang, tugas dan tanggungjawabnya dalam rangka pencapaian tujuan tugas pokok profesi dan terwujudnya tujuan dan sasaran unit organisasi (Suhartati, 2005). Hasil penelitian yang dilakukan oleh Tarigan dalam Manurung (2013) menemukan bahwa kinerja perawat pelaksana di RSU Kaban Jahe belum mampu memberikan pelayanan kesehatan yang terbaik kepada pasien, disebabkan oleh rendahnya motivasi kerja perawat sebagai pegawai institusi pemerintahan.

Dari hasil residensi angkatan II PSMIK UNHAS di RSU Bethesda Tomohon diketahui ada permasalahan dengan kepuasan kerja perawat baik dari kompensasi maupun motivasi perawat dalam melaksanakan tugas dan kerjanya sehingga berdampak pada kinerja perawat dalam melaksanakan asuhan keperawatan. Kompensasi mengenai insentif dan jasa pelayanan dirasakan perawat masih rendah. Begitu pula kepuasan kerja yang tidak sesuai dengan keinginan perorangan membuat perawat merasa kurang termotivasi dalam bekerja (Lombogia, 2012). Berdasarkan uraian diatas peneliti tertarik untuk menganalisis hubungan kompensasi dan kepuasan kerja dengan kinerja perawat melalui motivasi di ruang rawat inap RSU Bethesda Tomohon.

\section{METODE Desain Penelitian}

Desain penelitian menggunakan metode observasional analitik dengan pendekatan cross sectional study.

\section{Waktu dan Tempat Penelitian}

Penelitian ini dilakukan pada bulan Mei-Juni 2015 bertempat di ruang rawat inap RSU Bethesda 
Tomohon.

\section{Populasi dan Sampel}

Populasi adalah seluruh perawat di RSU Bethesda Tomohon dengan jumlah 82 orang. Sampel sebanyak 50 orang yang dipilih secara proportionate random sampling dan memenuhi kriteria inklusi yaitu 1) Perawat pelaksana dengan status pegawai tetap, 2) Perawat pelaksana dengan status pegawai kontrak yang bekerja lebih dari satu tahun. 3) Bersedia menjadi responden. Proportionate random sampling adalah teknik sampling pengambilan sampel dari tiap-tiap sub populasi dengan memperhitungkan besar kecilnya sub-sub populasi (Sugiyono, 2013). Sampel diambil dari masing-masing ruang perawatan sesuai dengan perhitungan besar sampel. Pengambilan sampel di setiap ruangan yaitu dengan melakukan memilih nama perawat yang memenuhi kriteria inklusi, sedangkan yang tidak memenuhi langsung dikeluarkan. Setelah adanya pemilihan nama perawat kemudian dilakukan undian nomor dari nama perawat untuk dijadikan sampel.

\section{Variabel}

Variabel dalam penelitian ini adalah sebagai berikut:

1. Variabel independent: kompensasi dan kepuasan kerja perawat.

2. Variabel intervening: motivasi.

3. Variabel dependent: kinerja perawat.

4. Variabel confounding: karakteristik perawat.

\section{Instrumen}

Metode pengumpulan data dalam penelitian ini menggunakan kuesioner dengan skala Likert yang terdiri dari: 12 item pernyataan untuk kompensasi, 19 item pernyataan untuk kepuasan kerja dan 14 item pernyataan untuk motivasi. Kuesioner yang digunakan sebelumnya telah memenuhi syarat uji validitas dan reliabilitas. Sedangkan untuk kinerja perawat menggunakan lembar observasi dengan skala Guttman sebanyak 20 item pernyataan. Pedoman observasi yang digunakan mengacu pada kriteria standar menurut Depkes (2004) dengan model skala Guttman dimana untuk lembar observasi akan diisi oleh peneliti.

\section{Analisis Data}

Data dianalisis berdasarkan skala ukur dan tujuan penelitian dengan menggunakan perangkat lunak program komputerisasi yaitu SPSS versi 20. Data dianalisis secara univariat untuk melihat distribusi frekuensi dari karakteristik responden dan setiap variabel. Analisis bivariat menggunakan uji Chi Square untuk menganalisa hubungan kompensasi dan kepuasan kerja perawat dengan kinerja perawat melalui motivasi di ruang rawat inap RSU Bethesda Tomohon.

\begin{tabular}{|c|c|c|c|}
\hline No & Nama Ruangan & Jumalah Perawat & Hasil \\
\hline 1. & Elisabeth & 22 & 13 \\
\hline 2. & Paulus & 11 & 7 \\
\hline 3. & Debora & 13 & 8 \\
\hline 4. & Bethesda & 13 & 8 \\
\hline 5. & Yohanes & 12 & 7 \\
\hline \multirow{2}{*}{6.} & Markus & 11 & 7 \\
\hline & Total & 82 & 50 \\
\hline
\end{tabular}

Tabe1 1. Distribusi pengambilan sampel setiap ruang rawat inap

\begin{tabular}{ccccccc}
\hline \multirow{2}{*}{ Variabel } & \multicolumn{2}{c}{ Jumlah Pertanyaan } & $\begin{array}{c}\text { No. Item Tidak } \\
\text { Valid }\end{array}$ & Validitas & Reliabilitas \\
\cline { 2 - 4 } Sebelum & Sesudah & & $8,14,15$ & $0.562-0.832$ & 0.931 \\
\hline Kompensasi & 15 & 12 & 19 & $5,11,15,17,19,22$ & $0.459-0.786$ & 0.937 \\
\hline Kepuasan Kerja & 25 & 14 & $5,12,14,18$ & $0.458-0.763$ & 0.881 \\
\hline Motivasi & 18 & 14
\end{tabular}

Tabel 2. Hasil uji validitas dan reliabilitas kuesioner $(\mathrm{n}=15)$ 
HASIL PENELITIAN

\begin{tabular}{|c|c|c|c|}
\hline \multirow{2}{*}{ NO } & \multirow{2}{*}{ Variabel } & \multicolumn{2}{|c|}{ Distribusi frekuensi } \\
\hline & & $\mathbf{N}$ & $\%$ \\
\hline & Umur & & \\
\hline \multirow[t]{3}{*}{1.} & Dewasa Awal & 37 & 74.0 \\
\hline & Dewasa Madya & 13 & 26.0 \\
\hline & Jenis Kelamin & & \\
\hline \multirow{3}{*}{2.} & Perempuan & 46 & 92.0 \\
\hline & Laki-laki & 4 & 8.0 \\
\hline & Pendidikan & & \\
\hline \multirow[t]{3}{*}{3.} & D3, D4 dan SPK & 44 & 88.0 \\
\hline & $\mathrm{S} 1, \mathrm{Ns}$ & 6 & 12.0 \\
\hline & Masa Kerja & & \\
\hline \multirow{3}{*}{4.} & 2-10 tahun & 29 & 58.0 \\
\hline & $>10$ tahun & 21 & 42.0 \\
\hline & Kompensasi & & \\
\hline \multirow[t]{3}{*}{5.} & Kurang & 29 & 58.0 \\
\hline & Baik & 21 & 42.0 \\
\hline & Kepuasan Kerja & & \\
\hline \multirow[t]{3}{*}{6.} & Kurang Puas & 30 & 60.0 \\
\hline & Puas & 20 & 40.0 \\
\hline & Motivasi & & \\
\hline \multirow[t]{3}{*}{7.} & Rendah & 19 & 38.0 \\
\hline & Tinggi & 31 & 62.0 \\
\hline & Kinerja Perawat & & \\
\hline \multirow[t]{2}{*}{8.} & Kurang & 27 & 54.0 \\
\hline & Baik & 23 & 46.0 \\
\hline
\end{tabular}

Tabe1 3. Distribusi frekuensi karakteristik responden $(n=50)$

\begin{tabular}{ccccccccc}
\hline \multirow{2}{*}{ Kompensasi } & \multicolumn{4}{c}{ Kepuasan Kerja Perawat } & \multirow{2}{*}{ Jumlah } & \multirow{2}{*}{$\begin{array}{c}\text { Perbandingan } \\
\text { Proporsi }\end{array}$} & Nilai p \\
\cline { 2 - 6 } & Kurang Puas & \multicolumn{2}{c}{ Puas } & & & \\
\cline { 2 - 6 } & $\mathbf{n}$ & $\%$ & $\mathbf{n}$ & $\%$ & $\mathbf{n}$ & $\%$ & \multirow{2}{*}{3.2} & 0.003 \\
\hline Kurang & 23 & 79.3 & 6 & 20.7 & 29 & 100 & \\
\hline Baik & 7 & 33.3 & 14 & 66.7 & 21 & 100 & & \\
\hline
\end{tabular}

Tabel 4. Analisis hubungan kompensasi dengan kepuasan kerja Perawat $(n=50)$

\begin{tabular}{|c|c|c|c|c|c|c|c|c|c|}
\hline \multirow{3}{*}{ No } & \multirow{3}{*}{ Variabel } & \multicolumn{4}{|c|}{ Motivasi Perawat } & \multirow{2}{*}{\multicolumn{2}{|c|}{ Jumlah }} & \multirow{3}{*}{$\begin{array}{c}\text { Perbandingan } \\
\text { Proporsi }\end{array}$} & \multirow{3}{*}{$\begin{array}{c}\text { Nilai } \\
\mathbf{p}\end{array}$} \\
\hline & & \multicolumn{2}{|c|}{ Rendah } & \multicolumn{2}{|c|}{ Tinggi } & & & & \\
\hline & & $\mathbf{n}$ & $\%$ & $\mathbf{n}$ & $\%$ & $\mathbf{n}$ & $\%$ & & \\
\hline \multirow[t]{3}{*}{1.} & Kompensasi & & & & & & & \multirow{3}{*}{1.7} & \multirow{3}{*}{0.040} \\
\hline & Kurang & 15 & 51.7 & 14 & 48.3 & 29 & 100 & & \\
\hline & Baik & 4 & 19.0 & 17 & 81.0 & 21 & 100 & & \\
\hline \multirow[t]{3}{*}{2.} & Ke p u a s a n & & & & & & & \multirow{3}{*}{2.1} & \multirow{3}{*}{0.002} \\
\hline & Kerja & 17 & 56.7 & 13 & 43.3 & 30 & 100 & & \\
\hline & $\begin{array}{l}\text { Kurang Puas } \\
\text { Puas }\end{array}$ & 2 & 10.0 & 18 & 90.0 & 20 & 100 & & \\
\hline
\end{tabular}

Tabel 5. Analisis hubungan kompensasi dan kepuasan kerja dengan motivasi ( $n=50)$ 


\begin{tabular}{|c|c|c|c|c|c|c|c|c|c|}
\hline \multirow{3}{*}{ No } & \multirow{3}{*}{ Variabel } & \multicolumn{4}{|c|}{ Motivasi Perawat } & \multirow{2}{*}{\multicolumn{2}{|c|}{ Jumlah }} & \multirow{3}{*}{$\begin{array}{c}\text { Perbandingan } \\
\text { Proporsi }\end{array}$} & \multirow{3}{*}{$\begin{array}{c}\text { Nilai } \\
\mathbf{p}\end{array}$} \\
\hline & & \multicolumn{2}{|c|}{ Rendah } & \multicolumn{2}{|c|}{ Tinggi } & & & & \\
\hline & & $\mathbf{n}$ & $\%$ & $\mathbf{n}$ & $\%$ & $\mathbf{n}$ & $\%$ & & \\
\hline \multirow[t]{3}{*}{1.} & Kompensasi & & & & & & & \multirow{3}{*}{1.7} & \multirow{3}{*}{0.040} \\
\hline & Kurang & 15 & 51.7 & 14 & 48.3 & 29 & 100 & & \\
\hline & Baik & 4 & 19.0 & 17 & 81.0 & 21 & 100 & & \\
\hline & Ke p u a s a & & & & & & & \multirow{3}{*}{2.1} & \multirow{3}{*}{0.002} \\
\hline & Kerja & 17 & 56.7 & 13 & 43.3 & 30 & 100 & & \\
\hline & $\begin{array}{l}\text { Kurang Puas } \\
\text { Puas }\end{array}$ & 2 & 10.0 & 18 & 90.0 & 20 & 100 & & \\
\hline \multirow[t]{3}{*}{3.} & Motivasi & & & & & & & \multirow{3}{*}{2.9} & \multirow{3}{*}{0.013} \\
\hline & Rendah & 15 & 78.9 & 4 & 21.1 & 19 & 100 & & \\
\hline & Tinggi & 12 & 38.7 & 19 & 61.3 & 31 & 100 & & \\
\hline
\end{tabular}

Tabel 6. Analisis hubungan kompensasi, kepuasan kerja dan motivasi dengan kinerja perawat di RSU Bethesda Tomohon Bulan Mei tahun 2015 ( $\mathrm{n}=50$ )

\section{Variabel Independent}

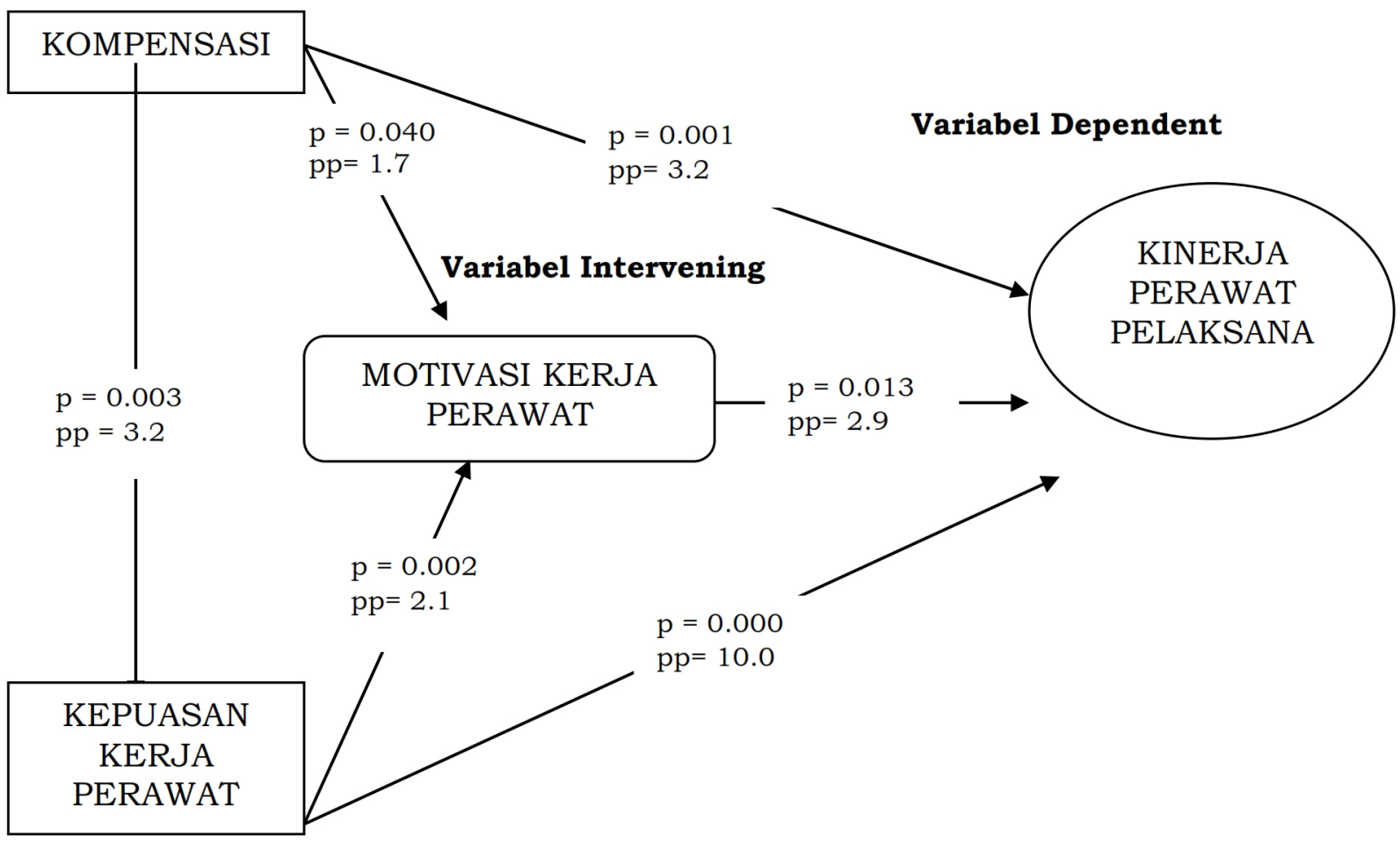

Gambar 1. Kerangka hasil penelitian

\section{Analisis Univariat}

Analisis univariat merupakan analisis yang dilakukan untuk melihat distribusi frekuensi dari variabel yang diteliti dalam bentuk tabel distribusi frekuensi. Berdasarkan tabel 3 diketahui bahwa responden terbanyak berada pada dewasa awal yaitu $74.0 \%$, berjenis kelamin perempuan yaitu $92.0 \%$, berada pada tingkat pendidikan D3, D4 dan SPK yaitu $88.0 \%$ dan berada pada masa kerja 2-10 tahun yaitu 58.0 \%. Sebagian besar responden sebanyak 29 orang (58\%) mengatakan kompensasi kurang dan sisanya 21 orang (42\%) mempersepsikan kompensasi baik. Responden mempersepsikan kepuasan kerja kurang puas 30 orang $(60 \%)$ dan sebaliknya 20 orang (40\%) mengatakan 
puas. Responden mempersepsikan motivasi tinggi yaitu 31 orang $(62.0 \%)$, sisanya 19 orang $(38 \%)$ mempersepsikan motivasi rendah. Dan responden terbanyak menunjukkan kinerja perawat kurang yaitu 27 orang $(54.0 \%)$ sedangkan 23 orang $(46 \%)$ menunjukkan kinerja baik.

\section{Analisis Bivariat}

Untuk menilai hubungan kompensasi dan kepuasan kerja dengan kinerja perawat melalui motivasi maka digunakan uji statistic chi square dengan tingkat kemaknaan $\mathrm{a}=0,05$ atau interval kepercayaan $\mathrm{p}$ $=0.05$.

Pada tabel 4, perawat yang mempersepsikan kompensasi baik dengan kepuasan kerja puas sebanyak 14 orang (66.7\%). Berdasarkan hasil uji statistik dengan menggunakan uji chi square diperoleh nilai $\mathrm{p}=0.003$ (a $<0.05$ ) dengan perbandingan proporsi 3.2, yang mana menunjukkan ada hubungan yang bermakna antara kompensasi dengan kepuasan kerja perawat.

Seperti yang terlihat pada tabel 5 , perawat yang mempersepsikan kompensasi baik dengan motivasi tinggi sebanyak 17 orang (81.0\%). Berdasarkan hasil uji statistik dengan menggunakan chi square diperoleh nilai $\mathrm{p}=0.040(\mathrm{a}<0.05)$ dengan perbandingan proporsi 1.7 , yang mana menunjukkan ada hubungan yang bermakna antara kompensasi dengan motivasi perawat, artinya hipotesa diterima. Hal ini berbeda dengan perawat yang mempersepsikan kepuasan kerja puas dengan motivasi tinggi sebanyak 18 orang (90.0\%). Berdasarkan hasil uji statistik dengan menggunakan uji chi square diperoleh nilai $\mathrm{p}=0.002(\mathrm{a}<0.05)$ dengan perbandingan proporsi 2.1 , yang mana menunjukkan ada hubungan yang bermakna antara kepuasan kerja dengan motivasi perawat.

Tabel 6 menunjukkan perawat yang mempersepsikan kompensasi baik dengan kinerja baik sebanyak 16 orang $(76.2 \%)$. Berdasarkan hasil uji chi square diperoleh nilai $\mathrm{p}=0.001$ (a $<0.05$ ) dengan perbandingan proporsi 3.2, yang mana menunjukkan ada hubungan yang bermakna antara kompensasi dengan kinerja perawat, artinya hipotesa diterima. Berbeda dengan perawat yang mempersepsikan kepuasan kerja puas dengan kinerja baik sebanyak 20 orang (100\%). Berdasarkan hasil uji statistik dengan menggunakan uji chi square diperoleh nilai $p=0.000(a<0.05)$ dengan perbandingan proporsi 10.0 , yang mana menunjukkan ada hubungan yang bermakna antara kepuasan kerja dengan kinerja perawat, artinya hipotesa diterima. Pada tabel ini juga dipaparkan perawat yang mempersepsikan motivasi tinggi dengan kinerja baik sebanyak 19 orang (61.3\%). Berdasarkan hasil uji statistik dengan menggunakan uji chi square diperoleh nilai $\mathrm{p}=0.013(\mathrm{a}<$ 0.05 ) dengan perbandingan proporsi 2.9, yang mana menunjukkan ada hubungan yang bermakna antara motivasi dengan kinerja perawat, artinya hipotesa diterima.

\section{PEMBAHASAN}

Dari hasil penelitian diketahui bahwa penelitian ini dapat menjawab penelitian umum yaitu dianalisis hubungan kompensasi dan kepuasan kerja perawat dengan kinerja perawat melalui motivasi di ruang rawat inap RSU Bethesda Tomohon. Penelitian ini menunjukkan ada hubungan yang bermakna hubungan kompensasi dengan kepuasan kerja perawat dengan perbandingan proporsi 2.4 kali perawat kurang puas dalam bekerja jika kompensasi yang diberikan kurang. Hasil penelitian ini sejalan dengan penelitian yang dilakukan oleh Dwaa (2006), menyatakan ada hubungan positif antara pemberian insentif, baik berupa uang maupun berupa jaminan sosial dengan kepuasan kerja karyawan, walaupun hubungan tersebut hanya sedang dan lemah. Hal ini didukung pendapat Robbins (2006), yang mengungkapkan bahwa kepuasan 
kerja merupakan sikap umum karyawan terhadap pekerjaannya berupa kesesuaian penghargaan yang diterima dengan penghargaan yang seharusnya diterima menurut perhitungannya sendiri. Dari hasil temuan ini peneliti berasumsi bahwa perawat akan memiliki kepuasan dalam bekerja jika ditunjang dengan kompensasi yang baik. Semakin tinggi kompensasi yang diberikan maka akan semakin puas perawat dalam bekerja.

Pada hubungan kompensasi dengan motivasi perawat dengan dengan perbandingan proporsi 2.7 dimana perawat dengan motivasi rendah berpeluang 2.7 kali merasa kompensasi kurang dibandingkan dengan perawat yang memiliki motivasi tinggi. Tetapi jika dipisahkan motivasi dalam 3 bagian teori McClelland, kebutuhan akan prestasi, kebutuhan akan kekuasaan dan kebutuhan akan afiliasi tidak ada yang menunjukkan hubungan bermakna dengan kompensasi. Hasil penelitian ini sejalan dengan penelitian Dwi (2008), bahwa ada hubungan antara persepsi terhadap kompensasi dengan motivasi kerja perawat ( $\mathrm{p}$-value 0,005). Semakin tinggi perawat mempersepsikan kompensasi maka semakin tinggi pula motivasi yang dipersepsikan perawat. Kompensasi dapat membuat karyawan lebih termotivasi untuk meningkatkan produktivitasnya dalam bekerja (Mondy et al., 2008). Menurut peneliti perawat akan lebih termotivasi jika kompensasi yang diberikan baik. Tetapi jika motivasi dibagi dengan 3 teori McClelland tidak ada hubungannya dengan kompensasi. Hal ini menjelaskan bahwa motivasi yang dirasakan perawat, kurang ataupun baik kompensasi yang dipersepsikan perawat itu tidak akan berpengaruh pada motivasi baik kebutuhan akan prestasi, kebutuhan akan kekuasaan dan kebutuhan akan afiliasi dalam dirinya.

Hasil analisis bivariat menunjukkan ada hubungan yang bermakna hubungan kepuasan kerja dengan motivasi perawat dengan perbandingan proporsi 5.7 dimana perawat dengan motivasi rendah berpeluang 5.7 kali merasakan kepuasan kerja kurang jika dibandingkan dengan perawat yang memiliki motivasi tinggi. Hasil penelitian ini sejalan dengan penelitian yang dilakukan Zaenudin (2012), ada hubungan antara motivasi akan kekuasaan, motivasi akan prestasi dan motivasi akan afiliasi dengan kepuasan kerja perawat di instalasi rawat inap BRSUD Kabupaten Batang dimana motivasi kerja dan kepuasan kerja yang tinggi dapat diciptakan dalam tim keperawatan dengan cara menjaga kekohesifan tim itu sendiri, saling mendukung dan nmemberikan kesempatan pengembangan pribadi dan professional sebagai bentuk support system yang positif. Menurut Robbins (2006), kepuasan kerja dapat merangsang semangat kerja dan loyalitas karyawan, sebaliknya tanpa ada kepuasan kerja maka karyawan akan cepat mengalami kebosanan, tidak bersemangat dalam bekerja, dan pindah pekerjaan. Peneliti berasumsi bahwa perawat akan lebih termotivasi jika merasakan puas dalam bekerja. Seseorang yang memiliki motivasi yang tinggi belum tentu merasa puas akan pekerjaannya. Tetapi semakin tinggi tingkat kepuasan kerja seseorang dapat meningkatkan motivasinya dalam bekerja.

Dari hasil tabel maupun gambar analisis bivariat menunjukkan ada hubungan yang bermakna hubungan kompensasi dengan kinerja perawat dengan perbandingan proporsi 3.2 dimana perawat dengan kinerja yang kurang berpeluang 3.2 kali untuk mendapatkan kompensasi kurang dibandingkan dengan perawat yang memiliki kinerja baik. Hasil penelitian ini sejalan dengan penelitian yang dilakukan Setiawan (2013), terdapat hubungan signifikan dengan arah yang positif antara variabel kompensasi dengan kinerja perawat dengan pengaruh yang terjadi adalah sangat 
kuat. Sistem kompensasi organisasi berdampak pada kinerja karyawan. Mengembangkan sistem kompensasi yang efektif dapat mempertahankan dan merekrut orang-orang yang berkompeten dan berbakat dalam mencapai misi dan tujuan organisasi (Robbins, 2006). Berdasarkan hal tersebut, menurut peneliti perawat akan bagus dalam kinerjanya jika diberikan kompensasi yang baik. Semakin tinggi kompensasi yang diberikan akan semakin baik kinerjanya dalam bekerja.

Untuk hubungan kepuasan kerja dengan kinerja perawat menunjukkan ada hubungan yang bermakna, dengan perbandingan proporsi 10.0 dimana perawat dengan kinerja yang kurang berpeluang 10.0 kali untuk mendapatkan kepuasan kerja kurang puas dibandingkan dengan perawat yang memiliki kinerja baik. Hasil penelitian ini sejalan dengan penelitian yang dilakukan Wahono (2012), bahwa secara parsial kepuasan kerja mempengaruhi kinerja perawat rumah sakit Islam Klaten. Hal ini berarti semakin tinggi tingkat kepuasan kerja perawat semakin baik pula kinerjanya. Menurut Brahmasari dalam Ranihusna (2010), kinerja karyawan sangat dipengaruhi oleh kepuasan kerjanya sendiri. Seorang karyawan akan lebih baik kinerjanya jika kepuasan akan kebutuhan dirinya dipenuhi oleh perusahan tempat dia bekerja. Menurut peneliti perawat akan bagus dalam kinerjanya jika diperhatikan kebutuhan akan kepuasan kerja perawat. Semakin tinggi tingkat kepuasan kerja yang dirasakan perawat maka akan semakin baik kinerjanya dalam bekerja.

Hasil analisis bivariat menunjukkan ada hubungan yang bermakna hubungan motivasi dan kinerja perawat dengan perbandingan proporsi 2.1 dimana perawat dengan kinerja yang kurang berpeluang 2.1 kali memiliki motivasi rendah dibandingakan jika kinerjanya baik. Seperti penelitian yang dilakukan oleh Hendrami (2009), yang membuktikan bahwa motivasi yang tinggi dari perawat akan meningkatkan kinerjanya menjadi lebih baik. Kinerja perawat yang baik dapat menjadi salah satu faktor meningkatnya kinerja rumah sakit karena perawat menjadi pintu utama dalam pelayanan kesehatan kepada masyarakat. Motivasi kerja yang tinggi menjadikan para karyawan mempunyai semangat yang tinggi untuk memberikan pelayanan yang terbaik bagi pasien sehingga pasien merasa puas dengan pelayanan yang diberikan (Badi'ah et al., 2009). Dari hal tersebut peneliti berasumsi perawat akan lebih baik kinerjanya jika memiliki motivasi yang tinggi dalam bekerja. Tetapi jika motivasi dibagi dengan 3 teori McClelland terdapat hubungan yang signifikan motivasi kebutuhan akan kekuasaan tetapi tidak terdapat hubungan motivasi kebutuhan akan prestasi dan kebutuhan akan afiliasi. Secara keseluruhan motivasi berhubungan dengan kinerja, dimana semakin tinggi motivasi akan semakin baik kinerjanya. Seseorang yang memiliki motivasi dalam dirinya jika ditunjang dengan kompensasi dan kepuasan kerja yang baik akan dapat meningkatkan kinerjanya lebih optimal.

Adapun keterbatasan dari penelitian ini adalah belum dilakukan penelitian tentang pengaruh yang menyebabkan masing-masing variabel saling berhubungan. Kiranya penelitian ini dapat menjadi panutan mengembangkan penelitian untuk mencari pengaruh dan seberapa besar pengaruh masing-masing variabel sehingga dapat saling mempengaruhi. Penelitian ini juga menggunakan instrumen kuesioner yang sudah dimodifikasi. Pada teknik pengambilan data terdapat beberapa kelemahan menggunakan kuesioner diantaranya kualitas data tergantung pada motivasi responden ketika menjawab kuesioner, kemungkinan ada salah persepsi dalam memahami makna pertanyaan, serta peneliti tidak dapat mengontrol kebenaran 
data yang diisi oleh responden. Namun instrumen penelitian ini telah dilakukan uji validitas dan realibilitas oleh peneliti sebelum digunakan dalam penelitian. Adapun keterbatasan yang lainnya adalah kurangnya referensi terkait teori dan penelitian tentang motivasi McClelland. Keterbatasan ini menyebabkan keterbatasan peneliti dalam melakukan pembahasan dengan menghubungkan motivasi menurut teori McClelland. Sedangkan keunggulan dari penelitian ini adalah penelitian ini merupakan penelitian terbaru yang mencari hubungan variabel independent dengan variabel dependent dimana ada variabel intervening. Penelitian ini juga menggunakan teori motivasi McClelland yang belum banyak diteliti. Hasil penelitian ini juga dapat membantu bidang manajemen rumah sakit untuk mengambil data dalam peningkatan kualitas pelayanan.

Implikasi penelitian ini dapat menjadi acuan bagi manajemen rumah sakit untuk memperhatikan kepuasan kerja perawat juga kompensasi yang diberikan. Dari hasil penelitian ini diketahui sebagian perawat pelaksana yang menjadi responden dalam penelitian ini mempersepsikan motivasi tinggi, sedangkan kompensasi dan kepuasan kerja dalam kategori kurang dan kurang puas. Sebagian perawat melaksanakan kinerja dalam kategori kurang. Kinerja yang kurang dapat dipengaruhi beberapa faktor yaitu misalnya kompensasi dan kepuasan kerja maupun motivasi dalam diri perawat itu sendiri sehingga kinerja perawat pelaksana kurang dalam pelaksanaan asuhan keperawatan. Dengan kinerja yang kurang dapat menurunkan pelayanan asuhan keperawatan kepada pasien. Dengan memperhatikan hal tersebut diharapkan kinerja perawat akan lebih optimal dan akan timbul motivasi dari dalam diri perawat tentang pentingnya pelaksanaan asuhan keperawatan yang professional sehingga pelayanan kesehatan di rumah sakit akan lebih baik. Sedangkan untuk dunia pendidikan, dalam menumbuhkan motivasi dalam diri masing-masing mahasiswa keperawatan yang nantinya akan menjadi perawat, hal yang harus dilakukan yaitu merubah cara pendang mahasiswa tentang keperawatan itu sendiri. Dengan memberikan pendidikan berupa case study diharapkan mahasiswa akan terlatih dan lebih memahami arti keperawatan sehingga jiwa perawat dalam diri mereka dapat meningkatkan komitmen untuk bersikap, berperilaku, dan melaksanakan asuhan keperawatan secara professional. Selain hal itu juga dengan memberikan contoh atau role model kepada mahasiswa tentang bagaimana sikap dan kinerja perawat yang seharusnya dilakukan saat sudah berhadapan dengan pasien, keluarga maupun dalam komunitas yang lebih besar.

\section{KESIMPULAN}

Berdasarkan hasil penelitian dapat disimpulkan terdapat hubungan yang signifikan antara kompensasi dan kepuasan kerja dengan kinerja perawat melalui motivasi. Semua variabel saling berhubungan satu dengan yang lain. Apapun karakteristik individu tidak berhubungan dengan kinerja perawat pelaksana di RSU Bethesda Tomohon.

Kepuasan kerja yang didalamnya juga ada kompensasi sangat mempengaruhi kinerja seseorang. Walaupun tanpa harus ditopang motivasi, tetapi seorang perawat tetap membutuhkan motivasi yang tinggi dalam dirinya untuk meningkatkan kinerjanya dalam pelayanan asuhan keperawatan dengan baik sehingga kepuasan kerja perawat dapat tercapai juga. Pihak manajemen rumah sakit harus memperhatikan kompensasi yang diberikan dan kepuasan kerja perawat sehingga perawat lebih termotivasi dalam melaksanakan pelayanan asuhan keperawatan secara professional sehingga kinerja perawat menjadi lebih optimal. Pemberian insentif maupun jasa pelayanan 
yang sesuai dengan kebijakan rumah sakit merupakan salah satu bentuk kompensasi yangrja perawat dapat meningkatkan motivasi perawat dalam melaksanakan asuhan keperawatan.

\section{DAFTAR PUSTAKA}

Badi'ah, A. et al. (2009). Hubungan motivasi perawat dengan kinerja perawat di ruang rawat inap Rumah Sakit Daerah Panembahan Senopati Bantul tahun 2008. Jurnal manajemen pelayanan kesehatan, Vol.12 No.2 hal 74-82

Dep.Kes RI. (2004). Konsep dan proses keperawatan. Jakarta : Dirjen Pelayanan Medik

Dwaa, S. (2006). Insentif dan Kepuasan Kerja Karyawan Dinas Kesehatan Provinsi Papua (Tesis, Universitas Gadjah Mada, Yogyakarta, Indonesia). Diakses dari http://sim.stikesaisyiyah.ac.id tanggal 30 Juni 2015

Dwi, A. (2008). Hubungan antara persepsi terhadap kepemimpinan dan kompensasi dengan motivasi kerja perawat di ruang rawat inap RSUD Dr. Moewardi Surakarta (Tesis, Universitas Diponegoro: Semarang

Hendrami, W. (2009). Pengaruh motivasi kerja terhadap kinerja tenaga perawat di instalasi rawat inap $R S H$. Adam Malik (Skripsi, Universitas Sumatra Utara, Medan, Indonesia). Diakses dari website http://repository.usu.ac.id tanggal 30 Juni 2015

Lombogia, M. (2012). Analisis praktek residensi manajemen keperawatan di Rumah Sakit Bethesda Tomohon (Laporan Praktek Residensi tidak dipublikasikan), Universitas Hasanuddin, Makassar

Manurung, A. (2013). Pengaruh kepemimpinan dan motivasi terhadap kinerja perawat $R S$ Bhayangkara Medan (Tesis, Universitas Sumatra Utara, Medan, Indonesia). Diakses dari website http://repository. usu.ac.id tanggal 2 Februari 2015.

Mondy, R.W., Robert, M.N., \& Shane, R.P. (2008). Human resource management (fifth edition). Massachusetts: Allyn and Bacon Ngatemin \& Arumwanti, W. (2012). Pengaruh kompetensi dan kompensasi terhadap motivasi kerja karyawan di kabupaten karo provinsi sumatera utara. Jurnal Riset Akuntansi dan Bisnis, Vol. 12 No. 2

Ranihusna, D. (2010). Efek rantai motivasi pada kinerja karyawan. Jurnal Dinamika Manajemen, Vol. 1 (2). pp90-103

Robbins, S.P. (2006). Prinsip-prinsip perilaku organisasi (edisi kelima). Jakarta: Erlangga

Setiawan, L. (2013). Hubungan kepuasan kompensasi dengan terhadap kinerja perawat di ruang rawat inap Rumah Sakit Kristen Ngesti Waluyo Parakan (Tesis, Universitas Gadja Mada, Indonesia). Diakses dari http://etd.repository.ugm. ac.id/ tanggal 30 Juni 2015

Siboro, E.D.S. (2012). Pengaruh motivasi terhadap kinerja perawat pelaksana di RSUD Perdagangan Kabupaten Simalungun (Tesis, Universitas Sumatra Utara, Medan, Indonesia). Diakses dari website http://repository.usu.ac.id tanggal 2 Februari 2015

Sugiyono. (2013). Metode penelitian manajemen: pendekatan kuantitatif, kualitatif, kombinasi (mixed methods), penelitian tindakan (action research), penelitian evaluasi. Bandung : Alfabeta

Suhartati. (2005). Pengembangan Manajemen dan Kinerja (PMK) Perawat dan Bidan. Media Pengembangan SDM Kesehatan, Vol. 1 No. 1. Diakses dari website http:// www.bppsdmk.or.id. tanggal 2 Februari 2015

Wahono, G.P. (2012). Pengaruh personorganization fit, kepuasan kerja dan komitmen organisasi terhadap kinerja perawat. Management Analysis Journal, 1 (1) ISSN 2252-6552

Winardi, (2007). Kepemimpinan dalam manajemen. Edisi kedua. Jakarta: Erlangga

Zaenudin, I.A. (2012). Hubungan antara motivasi kerja perawat dengan kepuasan kerja perawat di instalasi rawat inap badan RSUD Kabupaten Batang (Skripsi, Universitas Pekalongan, Indonesia) Diakses dari journal.unikal.ac.id tanggal 30 Juni 2015 